Іванова А. В. * (НУ «ОЮА»)

\title{
АНТИДИСКРИМІНАЦЙНА ПОЛІТИКА УКРАЇНИ В АСПЕКТІ ДЕМОКРАТИЧНИХ ПЕРЕТВОРЕНЬ
}

\section{ANTIDISCRIMINATION POLICY OF UKRAINE IN THE ASPECTS OF DEMOCRATIC TRANSFORMATIONS}

*Anastasiia Ivanova - PhD in Political Science, Political Theories Department, National University “Odesa Law Academy” (23, Fontanska Doroha St., Odesa, Ukraine).

\section{Abstract}

For Ukraine as a country of democratic transition, the high-priority direction of development is the establishment of democratic institutions, democratization, and liberalization of the political and legal system, especially in the direction of protection of human rights and freedoms. Within the framework of the development of the institutions of democracy, the establishment of the anti-discrimination course as a principle of state policy was considered a fundamental direction. This should be the basis for the development of tolerance as a democratic institution. The practical basis of which is legislative and law enforcement activities, the formation of a system of national legislation in the field of human rights protection, taking into account the recommendations and action plan of international organizations. Although Ukraine has ratified many international legal acts in the field of protection against various forms of discrimination, however, national legislation has gaps in the aspect of their practical implementation, as assessed by international organizations in the field of human rights protection.

The anti-discrimination state program should also include a set of measures (cultural, youth, social, information, educational state policies), including the establishment of specialized structures for monitoring the realization and actual implementation of anti-discrimination procedures.

The article focuses on the search for theoretical approaches to the study of discrimination in the aspect of building a democratic model of politics at the level 
of power, social power, and intersocial political interactions. Particular attention is paid to the foreign experience of the European Union, in particular, the rulemaking practices to improve the national concept of the development of the anti-discrimination strategy of the state.

Another important area of the article is the development of social institutions for the regulation of informal discrimination, which is widespread in interpersonal relations to form the principle of non-discrimination as a norm and value in the educational, cultural, social, legal and other social spheres. The anti-discrimination policy should be implemented by a coherent principle of functioning of state and social institutions.

Keywords: tolerance, discrimination, political stability, democratic transition, anti-discrimination policy.

Постановка проблеми. Український політичний процес не зважаючи на досить тривалий період та значний шлях політичних, економічних, культурних та інших трансформацій, досі характеризується успадкованими від Радянського Союзу ознаками. Політична система зазнала суттєвих процесів лібералізації, однак залишається проблема сповільненості нецілісності процесу демократизації. Специфіка змін торкнулася і перехідних процесів українського суспільства. Так одним $з$ провідних напрямків трансформацій, яких потребує українська політична система є проведення глибинних та дієвих реформ демократичних інститутів. Досить проблемним аспектом яких є питання побудування інституту толерантності та вироблення стратегії державної політики в сфері боротьби з проявами нетерпимості, зокрема дискримінацією. Дана проблематика досить широко досліджується у вітчизняних наукових кругах. Однак, в зарубіжній науковій думці має більш широку сферу дослідження. Ця стаття демонструє проблему дискримінації як одну з існуючих сторін сучасного процесу демократичного транзиту України.

Мета дослідження полягає в аналізі проблеми дискримінації та визначенні концептуальних засад антидискримінаційної політики держави в аспекті демократичного розвитку країни.

Аналіз основних досліджень та публікацій. Дискримінація як проблема демократичних трансформацій держав представлена в розробках зарубіжних та вітчизняних авторів М. Камалі, В. Вірма, Дж. Гібсона, Дж. Морено-Рианьо та ін. Дослідженнями деяких аспектів проблеми дискримінації займалися Л. Кормич, І. Галицький, С. Денисюк та ін. Поняття дискримінації концептуально досліджено 
I. О. Кресіною, К. М. Вітманом та ін. Автором досліджується низка моніторингових звітів та доповідей міжнародних організацій, Законів України та міжнародно-правових актів.

Україна як член Ради Свропи взяла на себе конвенційні зобов'язання забезпечення дотримання антидискримінаційної політики як фундаментального напрямку гарантії прав та свобод людини. Основний документ, що забезпечує захист від дискримінації це Європейська Конвенція прав людини. Необхідно зауважити, що на сьогодні саме Європейський Суд з прав людини розглядає справи, надає роз'яснення 3 приводу норм захисту права людини від будьякої форми дискримінації, що зобов' язує держави дотримуватися норм антидискримінаційного законодавства Європи. У 2000 році було підписано державами-членами Протокол N 12 до Конвенції про захист прав людини і основоположних свобод (ETS N 177), однак, досі не всіма учасниками-членами $Є C$ ратифіковано даний протокол. Який в свою чергу досить чітко формує приписи антидискримінаційних заходів. Як зазначається в Посібнику з європейського антидискримінаційного права в більшості документах Ради Європи міститься принцип недискримінації стосовно різних сфер і питань, зокрема в таких як Свропейська соціальна Хартія 1996 року, Рамковій конвенції про захист національних меншин, Конвенції Ради Європи про заходи щодо протидії торгівлі людьми, Конвенції Ради Європи про доступ до офіційних документів (Handbook on European nondiscrimination law, 2018, с. 13).

Дискримінацію можна визначити як позбавлення прав за ознакою належності до певних груп (за віком, расою, мовою, релігією, культурою, політичними поглядами, гендером, соціальним, економічним статусом та ін.), нетерпимість, несправедливе та упереджене ставлення та, виходячи з цього, надання певних привілеїв та преференцій тим, хто не відноситься до відзначеної групи, якщо це не $\epsilon$ об'єктивною правовою мірою, передбаченою законодавством.

Дослідник М. Камалі у визначенні дискримінації акцентує увагу на компонент зосередження суспільної свідомості на відмінності соціальних груп, та визначає, наступне: «Діферентності між різними соціальними групами набувають негативного характеру. Це не $є$ фактом різності в негативних категоріях, а це означає привласнення цих категорій цілим групам, що створює суспільне уявлення в значенні проти інших» (Kamali M., 2008, с. 67). Мова йде про уявлення, яке штучно запрограмоване в суспільній свідомості, де негативний 
компонент упереджено визначається як ознака соціальної групи. I на основі такого уявлення ці групи людей «маргіналізуються» та позбавляються чи утісняються в правах відносно інших.

У Кембриджському словнику дискримінація визначається як: «трактування людини або певної групи людей по-різному, в особливості якщо ви відноситеся в гіршій мірі до інших через їх колір шкіри, стать, сексуальність та ін.» (Cambridge dictionary, 2019). Таким чином, дискримінація може трактуватися як визначення пріоритетності тих чи інших людей в силу приналежності або неприналежності до тієї чи іншої групи. Все ж, можна відзначити складність об'єктивного визначення дискримінації. Наразі існує позитивна дискримінація, яка визначається як привілейованість груп, які зазнають найбільшого утиску. I. О. Кресіна визначає позитивну дискримінацію як низку: «...позитивних дій з метою покращення, виправлення дискримінованого становища певної особи або групи осіб, що зазнають найбільшого порушення прав» (Кресіна, 2016, с. 113). Це є досить розповсюдженою практикою в європейському просторі. Так, наприклад до займаних посад у політичній та державній владі впроваджують квотування для гендерної збалансованості та попередження гендерної дискримінації в державних структурах. Однак, противники подібних антидискримінаційних заходів вважають, що надання привілеїв з метою попередження дискримінацій у займанні посад, без належного концептуального розроблення, в тому числі на законодавчому рівні, може дійти до привілейованості дискримінованих груп та необ'єктивності призначення на посади, знехтування критерію професійності та дискримінації до інших кандидатів. Тому, особливу увагу законодавці в більшості європейських правових нормах приділяють процесу доведення факту дискримінації.

Антидискримінаційна політика для України має пріоритетне значення в аспекті демократичного державотворення та на шляху входження в Свропейський простір. Однак, неможливо зменшувати значення даного напрямку і для внутрішньої консолідації суспільства, вирішення існуючих деструктивних явищ міжсуспільних відносин, враховуючи багатоманітність та поліетнічну структуру українського суспільства. Для України як потенційного члена ЄС пріоритетним завданням є створення сприятливих умов розвитку меншин, їх всебічного захисту та безпечного співіснування на принципах плюралізму та толерантності на основі імплементації існуючих міжнародно-правових актів та створення національного законодав- 
ства в сфері захисту прав населення від різних форм дискримінацій. Зазначене завдання окреслено як пріоритетне і в Плані дій щодо лібералізації візового режиму СС для України, де в підрозділі 2.4. Блок 4: Зовнішні зносини та фундаментальні права відзначається щодо свободи пересування за необгрунтованими ознаками, в основі яких відноситься належність до певних соціальних груп, за переконаннями та іншими можливими критеріями дискримінації (План дій щодо лібералізації..., 2010, с. 8). А в пункті 2.4.3. Права громадян, включаючи захист меншин йдеться про необхідність ухвалення і розвитку антидискримінаційного законодавства, дотримання рекомендацій органів ООН, Ради Європи, ОБСЄ та ін., ратифікація документів в сфері забезпечення анти дискримінаційної політики в державі (План дій щодо лібералізації..., 2010, с. 9). Так само рекомендується окрім імплементації законодавства, також_іімплементація Плану дій щодо боротьби з дискримінацією», до чого і відноситься введення комплексного підходу для розширення обізнаності населення з протидії дискримінації та різних форм нетерпимості, а в особливості відзначається напрямок «зміцнення спроможності відповідальних органів у сфері антидискримінаційної політики та боротьби з расизмом, ксенофобією та антисемітизмом», в тому числі й навчання спеціальних підрозділів, які займаються конкретно злочинами на основі ненависті (План дій щодо лібералізації..., 2010, с. 8).

Як вище зазначено дискримінація в українському процесі має свою відкриту та латентну форму в площині суспільних інтеракцій. Більш широка інтерпретація також виділяє формальну чи неформальну дискримінацію. Так, наприклад, вітчизняний політолог I. O. Кресіна виокремлює офіційну та неофіційну дискримінацію, де першу розглядає як більш піддатливу до регулювання, в особливості акцентується увага на нормативно-правовий інструмент регулювання. Щодо неофіційної, вона стосується більш складного механізму виявлення, впливу та абсолютної ліквідації. Як відзначає вчена: «На відміну від офіційної дискримінації, яка відносно легко може бути нейтралізована шляхом внесення змін до нормативно правової бази, ліквідація неофіційної дискримінації потребує розробки та впровадження широкого спектру іноді унікальних для кожної країни політичних та соціальних механізмів протидії явищу» (Кресіна, 2016, с. 109). Можна говорити про проблему суспільного приховування випадків дискримінації в силу як правової бездіяльності правоохоронних органів, неефективності судової системи в справах щодо 
дискримінацій, так і певного конформного менталітету частини українців, успадкованого від Радянського минулого.

Згідно дослідженню підготовленого у 2015 році Інформаційноаналітичним центром «RATING PRO» на тему поширеності дискримінацій в українському суспільстві відзначається складність виявлення випадків дискримінацій на рівні суспільної свідомості: «...3 одного боку респонденти говорять про відсутність дискримінацій в Україні, з іншого - самі виявляють певний рівень несприйняття різних груп населення» (Поширення дискримінацій в Україні..., 2015). Практично до всіх представлених груп (сексуальні меншини, за віком і статтю, інвалідністю, расою, етнічністю) із особистого досвіду респондентів наявний значний рівень неприйняття, в той час як саме питання про існування дискримінації в Україні показує іï низьку поширеність на думку опитаних. Що свідчить про латентну форму інтолерантності в українському суспільстві. Наразі можна відзначити тенденцію неусвідомлення українцями форм нетерпимості як суспільної проблеми, зокрема дискримінації до різних груп населення, в той час як загальна картина свідчить про значний рівень суспільної нетерпимості до представлених в опитуванні груп. Ця форма провокує неприйняття інститутів толерантності у формі заперечення потреби ії розвитку чи недоцільності акцентування уваги на даному питанні, що аргументується відсутністю чи не пріоритетністю проблеми дискримінації в українському соціумі.

Слід відзначити, що введення алгоритму дотримання толерантності до різних соціальних, економічних, культурних статусів та груп на законодавчому рівні, може залишитися лише категоріями дозволів та заборон, однак не викоренити дискримінацію як соціальне явище. Тому, можна визначити, що формування стратегії антидискримінаціної політики повинне включати як засади правового складу, так і соціально-культурної політики, яка забезпечуватиме розвиток принципу анти дискримінації, враховуючи особливості та потреби конкретного суспільства.

Активне реформування антидискримінаційного законодавства отримало нову хвилю розвитку саме в процесі встановлення стандартів щодо візового режиму. В Указі Президента України «Про Національний план з виконання Плану дій щодо лібералізації Європейським Союзом візового режиму для України» від 22.04.2011, який з 20.10.2017 втратив чинність, були чітко встановлені цілі антидискримінаційного напрямку з метою реалізації Плану дій щодо лібералізації ЄС візового 
режиму для України в пункті 42 визначена ціль плану дій: «Схвалення Стратегії боротьби $з$ дискримінацією», в рамках якої визначено розробку Стратегії боротьби з дискримінацією в Україні (Указ Президента України Про Національний план з виконання Плану дій щодо лібералізації Європейським Союзом візового режиму для України, 2011). 3 метою виконання даної стратегії й було ухвалено Закон України «Про засади запобігання та протидії дискримінації в Україні», в якому досить широко інтерпретовано поняття дискримінації, визначено основні форми дискримінації та недискримінації, визначенні суб'єкти, які займаються питаннями попередження дискримінації та їх повноваження. Закон «Про засади запобігання та протидії дискримінації в Україні» 3 правками від 13.05.2014 є чинним.

Провідним принципом на якому заснована антидискримінаційна політика, в особливості, що стосується даного закону є принцип недискримінаційності. Так, в статті 2 визначається основні ознаки зазначеного принципу: «1) забезпечення рівності прав і свобод осіб та/або груп осіб; 2) забезпечення рівності перед законом осіб та/або груп осіб; 3) повагу до гідності кожної людини; 4) забезпечення рівних можливостей осіб та/або груп осіб» (Закон України «Про засади запобігання та протидії дискримінації в Україні», 2014). Грунтовне визначення дискримінаційності та дій, які не вважаються дискримінацією звужує можливості неправильної класифікації та толкування, що є дуже важливим для подальшого розгляду справ. На доповіді Європейської комісії проти расизму та нетерпимості щодо України від 20.06.2017 було визначено що даний закон практично в повній мірі визначає напрямки попередження та захисту від дискримінацій. Однак, СКРН виразила занепокоєність застиглим конфліктом на сході України та зростаючим на фоні анексії Криму антиросійською риторикою, що стає чинником погіршення відносин і всередині суспільства (Доповідь СКРН щодо України, 2017, с. 9). Військовий конфлікт на Сході України, окупація територій та політична криза $є$ сприятливим середовищем для формування різного роду нетерпимості в українському суспільстві. Породжені цими умовами питання мови та віри використовуються політиками як маніпулятивний інструмент для створення певних настроїв у суспільстві, що здебільш поширює соціально-політичну напругу та стає передвісником формування різного роду дискримінацій за політичними, етнічними, релігійними, мовними та регіональними ознаками, які є досить чутливими в українському суспільстві в силу історичних обставин. 
Досить вагомою проблемою в доповіді відзначається дискримінація до ЛГБТ-спільнот та етнічна дискримінація до Ромів в Україні (Доповідь ЄКРН щодо України, 2017, с. 9, 15). Не зважаючи на активне реформування та імплементацію Європейського законодавства в сфері захисту прав та свобод, СКРН у вищезазначеній Доповіді також відзначає існування деяких прогалин в антидискримінаційному законодавстві України. Зокрема, відзначається: «У кримінальному законі відсутнє посилання на розпалювання ненависті через сексуальну орієнтацію або гендерну ідентичність» (Доповідь ЄКРН щодо України, 2017, с. 14). СКРН рекомендувала створити спеціалізований орган з питань расової дискримінації, ксенофобії, антисемітизму, та рекомендувала надати повноваження розслідування таких випадків. Також вказано на проблеми «обов' язку доведення», через невичерпність визначення критеріїв дискримінації (Доповідь ЄКРН щодо України, 2017, с. 13). Наразі, досить глибокою проблемою можна вважати невідповідність офіційних та неофіційних статистичних даних щодо злочинів спричинених на мотиві ненависті, розпалюванні ворожнечі. В силу чого, на думку СКРН: «приблизно щодо чверті всіх злочинів, учинених на грунті нетерпимості, не було звернень у поліцію або поліція не визнала їх такими. До того ж, СКРН стало відомо, що працівники правоохоронних органів не завжди сприймають розпалювання ненависті серйозно та що, незважаючи на деякі нещодавні зусилля на іï реформування, довіра до поліції низька» (Доповідь СКРН щодо України, 2017, с. 15).

В світі проблем впровадження антидискримінаційної політики в систему роботи державних та правоохоронних органів, що зазначається в систематичних звітах моніторингових груп міжнародних організацій в сфері захисту прав людини проблема потребує цілісного розслідування. «За результатами звіту Уповноваженого Верховного комісара ООН щодо прав людини в Україні від 16 листопада 2017 15 лютого 2018 року, була відзначена занепокоєність проявами нетерпимості та відсутності ії протидії з боку правоохоронних органів: «...задокументовано 14 випадків дискримінації, мови ворожнечі та (або) насильства, спрямованих на осіб, які належать до меншин або дотримуються альтернативних, особливих соціальних або політичних думок. 12 із цих випадків мали місце у звітному періоді; до двох випадків були причетні правоохоронці, а у восьми випадках винуватцями були члени крайніх правих груп, які, як вбачається, діяли безкарно, тоді як поліція не бажала належним чином кваліфікувати та розслідувати такі злочини» (Доповідь щодо ситуації $з$ правами людини 188 
в Україні, с. 28), (Іванова, 2019, с. 167). Однак, моніторингові місії виконуючи функцію консультативну не мають змоги впливати на процес розслідування даних випадків дискримінацій та інтолерантності. Що абсолютно звужує можливості впливати на існуючі порушення.

Боротьба з дискримінацією та бездіяльністю до випадків дискримінації правоохоронних органів є центральним напрямком запропонованих Радою Європи в «Плані дій для України на 20182021 рр.», де визначається провідна мета, а саме: «Сприяння правам людини та людської гідності», де в рамках антидискримінаційних заходів зазначена: «стратегія інформаційної політики, спрямована на боротьбу з дискримінацією та на зміцнення потенціалу боротьби 3 дискримінацією в цільових групах, як-от: молодь, правоохоронні органи, судді, адвокати, працівники центрів безоплатної правової допомоги» (Рада Європи План дій для України на 2018-2021 рр., 2018, c. 12). I це повинно реалізовуватися в єдиній концепції узгодження нормотворчої бази згідно Європейських стандартів, в особливості стосовно кримінального та цивільного законодавства та ефективного звітування спеціальними органами та створення умов розслідування випадків дискримінацій (Рада Європи План дій для України на 20182021 рр., 2018, с. 14-15).

В рамках вищезазначеного курсу антидискримінаційної інформаційної політики для ефективного попередження дискримінацій в Україні вважаємо необхідним впровадження антидискримінаційної цензури на публічні виступи посадових осіб, в тому числі вищого рівня - Президента, чиновників та інших представників державних структур. Неможливо ефективно впроваджувати систему регулювання неофіційної дискримінації через створення заходів та інститутів, направлених на попередження та подолання проявів дискримінації, без належного формування політичної культури та політичної свідомості суспільства, на які особливий вплив має інформаційна політика держави.

Систематизація антидискримінаційних заходів повинна забезпечуватися і через функціонування низки соціально-політичних інститутів, які включатимуть як структуру, так і технічно-організаційні напрямки та ціннісно-нормативні заходи. 3 цією метою в країнах демократичного транзиту активно розвивається інститут толерантності при підтримці Європейської спільноти та міжнародних структур, чия сфера діяльності направлена на встановлення та розвиток прав та свобод людини. І це здебільш питання формування антидискримінаціоної соціальної політики держави. 
Як відзначає вітчизняний політолог К. Вітман: «ефективність антидискримінаційного законодавства однаковою мірою залежить від його змісту та ефективного застосування на практиці» (Вітман, 2012, с. 266). Разом $з$ тим, зрозуміло, що практична сторона, а саме діяльність спеціалізованих органів в попередженні, реагуванні, розслідуванні випадків дискримінації та як результат розгляду в судовому порядку таких справ і $є$ тією практичною стороною, яка в Україні поки що знаходиться на початковому етапі розвитку. Втім, Україна зробила успішний крок в законодавчій та нормотворчій сфері регулювання та попередження дискримінацій. Тож, в перспективі залишається розвиток практичних механізмів реалізації існуючого законодавчого базису в сфері антидискримінаційної політики держави.

Висновки. Узагальнюючи тему антидискримінаційної політики України в контексті демократичних перетворень в умовах європейського курсу розвитку можна визначити основні висновки.

Практика української політики показує значний прогрес в нормотворчій діяльності антидискримінаційного курсу держави в рамках процесів демократизації, однак основоположним підгрунтям повинна стати реформа судової системи. Більшість нормативноправових актів в сфері захисту прав людини та попередження дискримінацій ратифіковано Україною, однак в судовій сфері практично не розглядаються випадки дискримінації, подекуди трапляються поодиничні справи, однак загальноприйнята практика свідчить про низький рівень офіційної статистики щодо дискримінацій та злочинів скоєних на основі нетерпимості, про це вище зазначалося і в звітах моніторингових груп і міжнародних організацій з прав людини.

Для встановлення національної антидискримінаційної політики не зважаючи на нормативне узгодження з Свропейськими законодавством важливим залишається врахування національної особливості суспільства. В інакшому випадку, можна спостерігати мінімальний соціально-політичний ефект. Оскільки, концепція боротьби 3 дискримінацією лише на рівні законодавчих ініціатив не є комплексною та повинна включати роботу на рівні соціально-політичних процесів, освітньої, культурної, молодіжної політики. Саме ці заходи направлені на боротьбу з неофіційною дискримінацією, що поширюється на суспільному рівні та є одною з найбільших проблем демократизації українського суспільства. 


\section{Лimepamypa:}

Вітман К. М. (2012). Антидискримінаційне законодавство Молдови та України: проблеми імплементації. Публічне право, 4(8), 261-268.

Доповідь щодо ситуації з правами людини в Україні 16 листопада 2017 року - 15 лютого 2018 року. Управління Верховного комісара Організації Об'єднаних Націй з прав ююдини <https:/ / www.ohchr.org/ Documents/Countries/UA/ReportUkraineNov2017-Feb2018_UKR.pdf>. Закон Про засади запобігання та протидї дискримінацї̈ в Україні 2014 (Верховна Рада України). Офіційний сайт Верховної Ради України <https:/ / zakon.rada.gov.ua/laws/show/5207-17>.

Іванова А. В. (2019). Політична толерантність як імператив процесу забезпечення соціально-політичної стабільності. Одеса: Нац. ун-т «Одеська юридична академія».

Кресіна I. О. (2016). Проблеми законодавчого забезпечення антидискримінаційної політики в Україні. Суспільно-політичні процеси, 2, 109-124.

План дій для України на 2018-2021 рр. Портал Ради Європи. <https:/ /rm.coe.int/coe-action-plan-for-ukraine-2018-2021-ukr/1680925bec>.

План дій щодо лібералізації СС візового режиму для України. Урядовии nортал. <http:/ / www.kmu.gov.ua/ document/244813925/План\% 20 д_й\%20щодо\%20л_берал_зац_\%20_С\%20в_зового\%20режи му\%20 для\%20Укра_ни.pdf>.

Поширення дискримінацій в Україні. Інформаційно-алалітичний цзентр «RATINGPRO»<http:/ / ratinggroup.ua/files/ratinggroup/reg_files/ rp_discrimination_072015.pdf>.

Указ Президента України Про Національний план з виконання Плану дій щзодо лібералізації Європейським Союзом візового режиму для України 2011 (Президент України). Офіційний сайт Верховної Ради України. <https:/ / zakon.rada.gov.ua/laws/show/494/2011>.

Доповідь ЄКРН щодо України (п'ятий цикл моніторингу) 2017 (Європейська комісія проти расизму та нетерпимості). Council of Europe portal. <https:/ / rm.coe.int/ fifth-report-on-ukraine-ukrainian-translation/16808b5caa>.

Handbook on European non-discrimination law 2018. Luxembourg: Publications Office of the European Union. <https:/ / www.echr.coe.int/ Documents/Handbook_non_discri_law_ENG.pdf $>$. 
Kamali M. (2008). Racial Discrimination: Institutional Patterns and Politics. United Kingdom: Routledge.

Discrimination. Cambridge dictionary < https:/ / dictionary.cambridge.org/ dictionary/english/discrimination>.

\section{References:}

Discrimination. Cambridge dictionary < https:/ / dictionary.cambridge.org/ dictionary/english/discrimination>.

Dopovid shchodo sytuatsii z pravamy liudyny v Ukraini 16 lystopada 2017 roku 15 liutoho 2018 roku [Report on the situation of human rights in Ukraine on November 16, 2017 - February 15, 2018.]. Upravlinnia Verkhovnoho komisara Orhanizatsii Ob'iednanykh Natsii z prav liudyny [United nations human rights office of the high commissioner]. Retrieved from https://www.ohchr. org/Documents/Countries/UA/ReportUkraineNov2017-Feb2018_UKR. pdf [in Ukrainian].

Dopovid YeKRN shchodo Ukrainy (p'iatyi tsykl monitoryngu) 2017 (Yevropeiska komisiia proty rasyzmu ta neterpymosti) [ECRI report on Ukraine (Fifth monitoring cycle) 2017 (European Commission against Racism and Intolerance)]. Council of Europe portal. <https:/ / rm.coe.int/ fifth-report-onukraine-ukrainian-translation-/16808b5caa> [in Ukrainian].

Handbook on European non-discrimination law 2018. Luxembourg: Publications Office of the European Union. <https://www.echr.coe.int/ Documents/Handbook_non_discri_law_ENG.pdf>.

Ivanova A. V. (2019). Politychna tolerantnist yak imperatyv protsesu zabezpechennia sotsialno-politychnoi stabilnosti [Political Tolerance as an Imperative of the Process of Ensuring Socio-Political Stability]. Odesa: Nats. un-t "Odeska yurydychna akademiia". [in Ukrainian].

Kamali M. (2008). Racial Discrimination: Institutional Patterns and Politics. United Kingdom: Routledge.

Kresina I. O. (2016). Problemy zakonodavchoho zabezpechennia antydyskryminatsiinoi polityky v Ukraini [Problems of Legislative Support of Anti-Discrimination Policy in Ukraine]. Suspilno-politychni protsesy [Social-political processes], no. 2, 109-124 [in Ukrainian].

Plan dii dlia Ukrainy na 2018-2021 rr [Action Plan for Ukraine for 2018-2021]. Portal Rady Yevropy [Portal of the Council of Europe.]. <https:/ / rm.coe.int/ coe-action-plan-for-ukraine-2018-2021-ukr/1680925bec> [in Ukrainian].

Plan dii shchodo liberalizatsii YeS vizovoho rezhymu dlia Ukrainy [Action Plan on EU Visa Liberalization for Ukraine]. Uriadovyi portal [Government 
portal]. <http://www.kmu.gov.ua/document/ 244813925/Plan\%20 d_i\%20shchodo\%201_beral_zats_\%20_S\%20v_zovoho\%20rezhy mu $\% 20$ dlia\%20Ukra_ny.pdf> [in Ukrainian].

Ukaz Prezydenta Ukrainy Pro Natsionalnyi plan z vykonannia Planu dii shchodo liberalizatsii Yevropeiskym Soiuzom vizovoho rezhymu dlia Ukrainy 2011 (Prezydent Ukrainy) [Decree of the President of Ukraine On the National Plan for the Implementation of the Action Plan for the Liberalization of the European Union Visa Requirements for Ukraine 2011 (Verkhovna Rada of Ukraine)]. Ofitsiinyi sait Verkhovnoi Rady Ukrainy [The official website of the Verkhovna Rada of Ukraine]. <https:/ / zakon.rada.gov.ua/laws/ show/494/2011> [in Ukrainian].

Vitman K. M. (2012). Antydyskryminatsiine zakonodavstvo Moldovy ta Ukrainy: problemy implementatsii [Discriminatory Legislation of Moldova and Ukraine: Implementation Issues]. Publichne pravo [Public Law], no. 4(8), 261-268 [in Uktainian]

Zakon Pro zasady zapobihannia ta protydii dyskryminatsii v Ukraini 2014 (Verkhovna Rada Ukrainy) [The Law on the Principles of Prevention and Countering Discrimination in Ukraine 2014 (Verkhovna Rada of Ukraine)]. Ofitsiinyi sait Verkhoonoi Rady Ukrainy [The official website of the Verkhovna Rada of Ukraine]. <https://zakon.rada.gov.ua/laws/show/5207-17> [in Ukrainian].

\section{Анотація}

ІВанова А. В. Антидискримінаційна політика Украйни $b$ аспекті демократичних перетворенъ. - Стаття.

У статті аналізується засади антидискримінаційної політики держави, специфіки регулювання та попередження дискримінацій, характер впливу на соціально-політичну стабільність в контексті демократичних трансформацій украӥнського політичного процесу. Акцентується увага на пошуку теоретичних підходів дослідження проблеми дискримінації $b$ аспекті побудування демократичної моделі політики як на рівні суто владних, суспільно-Владних так і міжсоціальних політичних взаємодій. У статті досліджуються механізми гармонізації та інституціоналізації політичного процесу, які реалізуються в українській антидискримінаційній політиці держави. Також особлива увага приділяється зарубіжному досвіду Європейського Союзу, В особливості нормотворчих практик для удосконалення національної концепції розвитку антидискримінаційної стратегії держави.

Ключові слова: толерантність, дискримінація, політична стабільність, демократичний транзит, антидискримінаційна політика. 